\title{
METHOD DEVELOPMENT AND VALIDATION FOR ESTIMATION OF CURCUMIN AND PIPERINE BY RP-HPLC
}

\author{
RAMYA KUBER B. \\ Institute of Pharmaceutical Technology, Sri Padmavati Mahila Visvavidyalayam, Tirupati-517502 \\ Email: ramyakuber@gmail.com
}

Received: 26 Sep 2018, Revised and Accepted: 12 Dec 2018

ABSTRACT

Objective: To develop a simple, sensitive, specific, accurate reverse phase high performance liquid chromatographic (RP-HPLC) method for the estimation of curcumin and piperine.

Methods: The separation was done using a column Inertsil-ODS $\mathrm{C}_{18}(250 \mathrm{~mm} \times 4.6 \mathrm{~mm}, 5 \mu$ particle size) and mobile phase composed of methanol: water (45:55 v/v), flow rate at $1 \mathrm{ml} / \mathrm{min}$ and detection was carried out at $282 \mathrm{~nm}$ with photodiode array (PDA) detector.

Results: The separation of curcumin and piperine were found to be at the retention time of 2.433 min and 3.095 min, respectively. The method was found to be linear at a concentration range $20-80 \mu \mathrm{g} / \mathrm{ml}$ for curcumin and piperine. The limit of detection (LOD) and limit of quantification (LOQ) was found to be $0.05 \mu \mathrm{g} / \mathrm{ml}$ and $0.17 \mu \mathrm{g} / \mathrm{ml}$ for curcumin and $0.18 \mu \mathrm{g} / \mathrm{ml}$ and $0.53 \mu \mathrm{g} / \mathrm{ml}$ for piperine respectively. The average percentage recoveries of curcumin and piperine were in the range of $98-100.6 \%$.

Conclusion: A simple and sensitive reverse phase high performance liquid chromatographic method was developed for the estimation of curcumin and piperine.

Keywords: Method development, Method validation, RP-HPLC, Curcumin, Piperine

(c) 2019 The Authors. Published by Innovare Academic Sciences Pvt Ltd. This is an open access article under the CC BY license (http://creativecommons.org/licenses/by/4.0/) DOI: http://dx.doi.org/10.22159/ijap.2019v11i1.29971

\section{INTRODUCTION}

Curcumin is principal curcuminoid of indian spice turmeric of ginger Curcuma longa Linn. (family: Zingiberaceae). It has antioxidant, antiinflammatory, anti-fungal, anti-viral action [1] and anti-carcinogenic action [2]. Curcumin is chemically called as 1,7-bis(4-hydroxy-3methoxyphenyl)-1,6-heptadien-3,5-dione, structurally it was shown in fig. 1 [3]. Piperine was first pharmacologically active compound isolated from Piper longum and Piper nigrum (family: Piperaceae) [4]. Piperine(1-peperoyl piperidine) exhibits pharmacological activities like anti-hypertensive, anti-platelet [5], and anti-asthamatic, antitumor activities [6]. Literature survey revealed that few analytical methods were reported for the estimation of curcumin and piperine. Previously reported methods were U. V. Spectroscopy [7-13], HPLC [14-20], HPTLC [21], UFLC [22], LC-MS/MS [23], GC-MS [24] for curcumin and piperine, individually or in combination with other drugs. Based on literature it was confirmed that few HPLC methods were reported for simultaneous estimation of curcumin and piperine. The present method was simple, sensitive, and selective and developed with low-cost solvent in the mobile phase and simple standard preparation and separation were done at shorter run time and all parameters were validated according to ICH guidelines [25].<smiles>COC1=CC2(/C=C/C(=O)CC(=O)/C=C/c3ccc(O)c(OC)c3)CCC1(O)CC2</smiles>

Fig. 1: structure of curcumin<smiles>O=C(/C=C/C=C/c1ccc2c(c1)OCO2)N1CCCCC1</smiles>

Fig. 2: structure of piperine

\section{MATERIALS AND METHODS}

\section{Instrument}

The method was developed with the system composed of Waters HPLC, Model No 2690/5 series. The chromatographic separation was done on Inertsil- $C_{18}$ ODS column.

\section{Chemical solutions and reagents}

Curcumin and piperine were supplied from spectrum pharmaceuticals Pvt, Ltd, kukatpally, Hyderabad. Orthophosphoric acid, Acetonitrile (HPLC grade), Water (HPLC grade) was purchased from Merck chemicals private limited (Mumbai, India).

\section{Chromatographic conditions}

The chromatographic separation was done with different solvents, finally a good resolution was achieved with a mobile phase methanol and water $(45: 55, \mathrm{v} / \mathrm{v})$ using Inertsil-ODS $\mathrm{C}_{18}$ column, at a flow rate 1 $\mathrm{ml} / \mathrm{min}$. The chromatographic detection was carried at $282 \mathrm{~nm}$, with PDA detector.

\section{Preparation of standard and working standard solutions}

Weigh $10 \mathrm{mg}$ of curcumin and piperine and dissolved in $10 \mathrm{ml}$ of calibrated volumetric flasks separately, add $10 \mathrm{ml}$ of mobile phase and sonicated for $20 \mathrm{~min}$. $0.4 \mathrm{ml}$ was taken from above stock solution and transferred into $10 \mathrm{ml}$ volumetric flask and add $10 \mathrm{ml}$ of mobile phase.

\section{Mobile phase composition}

Different trails were done for estimation of curcumin and piperine with the different combination of solvents with different ratios like $(90: 10,60: 40,50: 50$, and 40:60). Finally, methanol and water $(45: 55, v / v)$ were selected because of peak symmetry, the good resolution between curcumin and piperine.

\section{Method validation}

The method was validated according to ICH guidelines, 2005 . Validation parameters were according to guideline of ICH Q2R1. Validation parameters include system suitability, linearity, precision, LOD, LOQ, accuracy and robustness, ruggedness. 


\section{Specificity}

Specificity was established by comparing analytic chromatographic peak with the blank. No predictable peak was found at the retention time of curcumin and piperine. The data was given in fig. 3, 4, and 5 .

\section{Linearity and calibration curve}

The linearity range was estimated between $20-80 \mu \mathrm{g} / \mathrm{ml}$ for curcumin and piperine. The calibration curve was plotted between concentration against corresponding peak area using least square method.

\section{Precision}

The precision of the method was evaluated with same concentration level, six replicate injections were injected and precision was expressed in terms of intra-day (repeatability) and inter-day precision and was conveyed in terms of percent relative standard deviation (\%RSD).

\section{Accuracy (\% recovery)}

Accuracy of the method was evaluated using standard addition method, where standard was spiked at 50\%, 100\%, 150\% levels and accuracy was estimated with percentage recovery and percentage relative standard deviation (\%RSD).

\section{Robustness}

Robustness was evaluated by making small deliberate changes in flow rate, temperature, mobile phase composition, provides an indication of the reliability of the method.

\section{Ruggedness}

Ruggedness of the method was studied on different HPLC systems, under similar conditions at different times.

\section{LOD and LOQ}

LOD and LOQ were estimated using slope (S) and standard deviation of intercept $(\alpha)$ from the calibration curve.

$\mathrm{LOD}=3.3 \alpha / \mathrm{S}$

$\mathrm{LOQ}=10 \alpha / \mathrm{S}$

$\alpha$ is the standard deviation of $y$-intercept and $S$ is a slope from linearity plot.

\section{RESULTS}

\section{Optimization of chromatographic conditions}

The chromatographic separation was done with various trails using different conditions. Based on theoretical plates, peak shape and back pressure, the column was selected. Finally, the chromatographic separation was carried out using Inertsil-ODS $\mathrm{C}_{18}$ column $(250 \mathrm{~mm} \times 4.6 \mathrm{~mm}$; $5 \mu$ particle size $)$ and mobile phase methanol: water $(45: 55 \mathrm{v} / \mathrm{v})$ at a flow rate $1 \mathrm{ml} / \mathrm{min}$ and injection volume $10 \mu \mathrm{l}$ and detection at $282 \mathrm{~nm}$ with PDA detector. The retention time was found to be $2.433 \mathrm{~min}$ for curcumin and 3.095 min for piperine. The optimized chromatographic conditions were shown in table 1 and the chromatogram of blank, standard, and sample was shown in fig. $3,4,5$.

Table 1: Optimized chromatographic conditions for estimation of curcumin and piperine

\begin{tabular}{ll}
\hline Parameter & Condition \\
\hline Stationary phase(Column) & Inertsil-ODS $\mathrm{C}_{18}(250 \mathrm{~mm} \times 4.6 \mathrm{~mm}, 5 \mu)$ \\
Mobile phase & Methanol: water $(45: 55 \mathrm{v} / \mathrm{v})$ \\
Column temperature & Ambient \\
Detection wave length & $282 \mathrm{~nm}$ \\
Injection volume & $20 \mu \mathrm{l}$ \\
Flow rate & $1 \mathrm{ml} / \mathrm{min}$ \\
Run time & $10 \mathrm{~min}$ \\
Retention time & $2.433 \mathrm{~min}$ for curcumin, $3.095 \mathrm{~min}$ for piperine \\
\hline
\end{tabular}

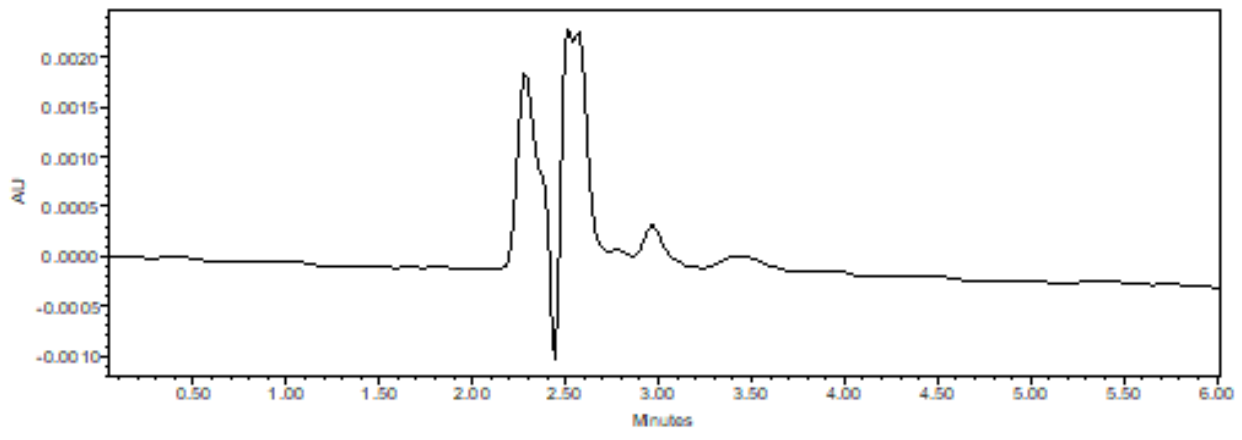

Fig. 3: Typical HPLC chromatogram of blank

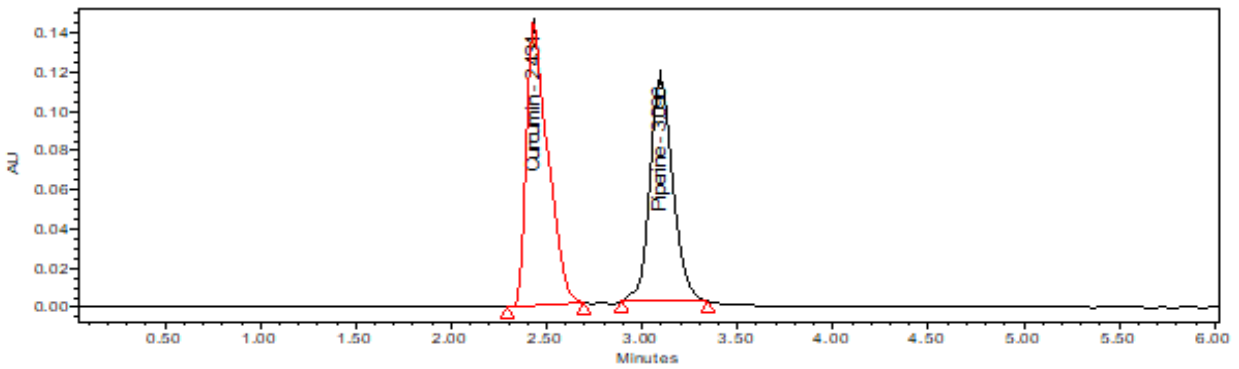

Fig. 4: Typical HPLC chromatogram of standard 


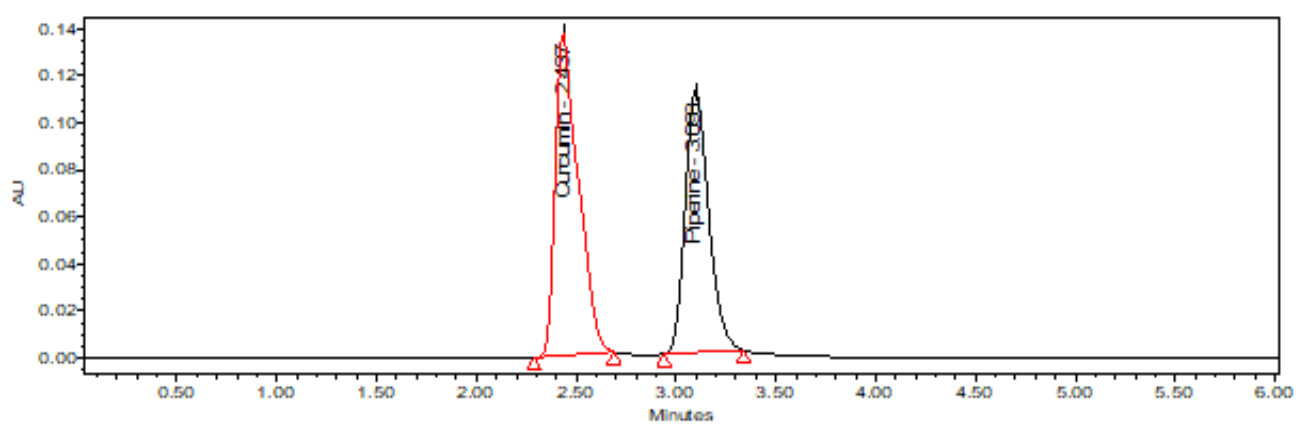

Fig. 5: Typical HPLC chromatogram of sample

\section{Method validation}

\section{System suitability}

System suitability tests were carried out to make sure that optimized chromatographic conditions are suitable for estimation of curcumin and piperine. Standard solution containing a mixture of curcumin and piperine $(40 \mu \mathrm{g} / \mathrm{ml})$ was prepared. Six replicate injections from above standard solutions were injected into column and verify system suitability parameters like theoretical plate count, tailing factor, retention time, resolution, and percentage relative standard deviation of the peak for chromatograms. The developed method had shown more than 2000 theoretical plates, the percentage relative standard deviation for peak area and retention times were less than 2 and tailing factor less than 2, which ensure the suitability of developed method. The results were shown in table 2 .

Table 2: System suitability of curcumin and piperine

\begin{tabular}{llll}
\hline Parameter & Curcumin & Piperine & Acceptance criteria \\
\hline Retention time & $2.437 \mathrm{~min}$ & $3.097 \mathrm{~min}$ & $\ldots \ldots$. \\
Theoretical plates & 5934.2 & 8730.4 & $>2000$ \\
Tailing factor & 1.24 & 1.11 & $<2$ \\
\hline
\end{tabular}

\section{Specificity}

Specificity was carried out by evaluation of blank, standard and sample injections. The resultant chromatograms of blank, standard and sample were compared, the correlation was good between standard and sample and no interference of excipients in blank with drug was observed. The data was shown in fig. 3,4 , and 5 .

\section{Linearity}

The linearity of the method was determined at seven concentration levels ranging from $20-80 \mu \mathrm{g} / \mathrm{ml}$ for curcumin and piperine. The regression line equation for curcumin was $Y=32252 \mathrm{X}-40399$ and for piperine was $Y=25780 \mathrm{X}+2765$. The correlation coefficient values were found to be 0.999 and 0.999 for curcumin and piperine. The regression data for the calibration curve had shown a good linear relationship over a concentration range $20-80 \mu \mathrm{g} / \mathrm{ml}$ for curcumin and piperine. The results of the regression were summarized in table 3 and 4 and data was shown in fig. 6

\section{Precision}

The precision of the developed method was checked in terms of repeatability (intra-day precision) and inter-day precision, which shown percent relative standard deviation (\% RSD) less than 2, ensures precision of the developed method. The results were shown in table 5 and 6.

\section{Accuracy}

Accuracy of the method was examined by performing the recovery of added standard to the drug product was calculated, and it was found to be $98-100.6 \%$ with \%RSD less than 2 , which indicate the method was accurate. The results were summarized in table 7 and 8.

\section{Robustness}

Robustness of the method was checked by the slight variation in flow rate, which shown that no significant changes in the validation parameter. The results of variation in flow rate were given in table 9 and 10.

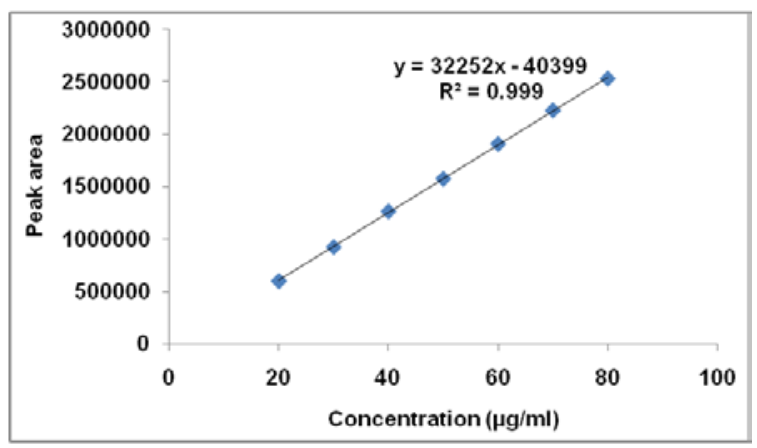

[A]

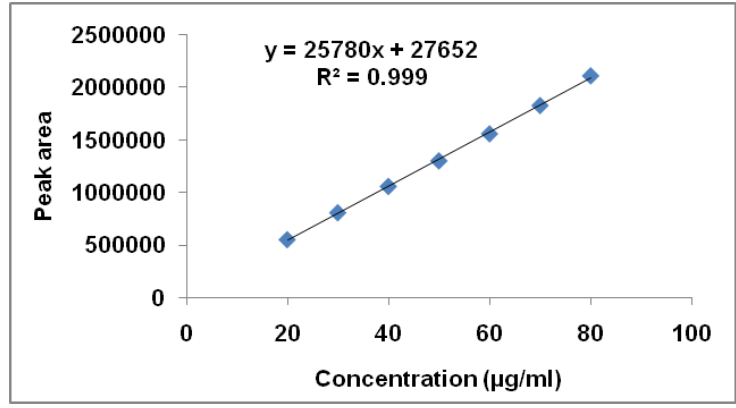

[B]

Fig. 6: Standard calibration curve of $[A]$ curcumin $[B]$ piperine 
Table 3: Linearity and range of curcumin

\begin{tabular}{lll}
\hline S. No. & Concentration $(\boldsymbol{\mu g} / \mathbf{m l})$ & Peak area \\
\hline 1 & 20 & 598203 \\
2 & 30 & 921576 \\
3 & 40 & 1260823 \\
4 & 50 & 1571434 \\
5 & 60 & 1904090 \\
6 & 70 & 2222634 \\
7 & 80 & 2526577 \\
Slope & & 32252 \\
Y-intercept & & 40399 \\
Correlation coefficient & & 0.999 \\
\hline
\end{tabular}

Table 4: Linearity and range of piperine

\begin{tabular}{lll}
\hline S. No. & Concentration $(\boldsymbol{\mu g} / \mathbf{m l})$ & Peak area \\
\hline 1 & 20 & 551566 \\
2 & 30 & 807869 \\
3 & 40 & 1058029 \\
4 & 50 & 1301310 \\
5 & 60 & 1559184 \\
6 & 70 & 1828268 \\
7 & 80 & 2110397 \\
Slope & & 25780 \\
Y-intercept & & 27652 \\
Correlation coefficient & & 0.999 \\
\hline
\end{tabular}

Table 5: Intra-day and inter-day precision of the developed method for curcumin $(n=6)$

\begin{tabular}{|c|c|c|c|c|c|}
\hline \multirow[t]{2}{*}{ Drug } & \multirow[t]{2}{*}{ Concentration $(\mu \mathrm{g} / \mathrm{ml})$} & \multicolumn{2}{|l|}{ Intra-day precision } & \multicolumn{2}{|c|}{ Inter-day precision } \\
\hline & & (mean \pm SD) & \%RSD & (mean \pm SD) & \%RSD \\
\hline Curcumin & 40 & $1266128 \pm 3958.6$ & 0.3 & $1266921 \pm 2370.2$ & 0.2 \\
\hline
\end{tabular}

$\mathrm{n}$ is number of determinations, SD is standard deviation, RSD is relative standard deviation

Table 6: Intra-day and inter-day precision of the developed method for piperine (n=6)

\begin{tabular}{lllll}
\hline Drug & Concentration $(\mu \mathrm{g} / \mathrm{ml})$ & \multicolumn{2}{l}{ Inter-day precision } & \multicolumn{2}{l}{ Intra-day precision } & \%RSD & (mean \pm SD) & \%RSD & (mean \pm SD) & 0.4 & $1056681 \pm 3304.6$ \\
\hline Piperine & 40 & $1053989 \pm 3924.2$ & 0.3 & \\
\hline
\end{tabular}

$\mathrm{n}$ is number of determinations, SD is standard deviation, RSD is relative standard deviation

Table 7: Accuracy of the developed method for curcumin $(n=3)$

\begin{tabular}{lllll}
\hline Drug name & Level of addition (\%) & Amount added (mg) & $\begin{array}{l}\text { Drug found (mg/ml) } \\
\text { (mean } \pm \text { SD) }\end{array}$ & \% recovery (mean \pm SD) \\
\hline \multirow{3}{*}{ Curcumin } & 50 & 20 & $19.9 \pm 0.13$ & $99.9 \pm 0.7$ \\
& 100 & 20 & $40.02 \pm 0.3$ & 0.7 \\
\hline
\end{tabular}

$\mathrm{n}$ is number of determinations, SD is standard deviation

Table 8: Accuracy of the developed method for piperine $(n=3)$

\begin{tabular}{llllc}
\hline Drug name & Level of addition (\%) & Amount added (mg) & Drug found (mg/ml) (mean \pm SD) & $\begin{array}{c}\text { \% recovery } \\
\text { (mean } \pm \text { SD) }\end{array}$ \\
\hline \multirow{3}{*}{ Piperine } & 50 & 20 & $19.9 \pm 0.1$ & $99.4 \pm 0.4$ \\
& 100 & 20 & $39.7 \pm 0.2$ & 0.4 \\
& 150 & 20 & $60 \pm 0.1$ & 0.2 \\
\hline
\end{tabular}

$\mathrm{n}$ is number of determinations, SD is standard deviation

Table 9: Robustness of curcumin $(n=6)$

\begin{tabular}{llll}
\hline S. No. & Flow rate (ml/min) & Peak area (mean \pm SD) & Tailing factor (mean \pm SD) \\
\hline 1 & 0.8 & $1294922 \pm 3898.9$ & $1.23 \pm 0.005$ \\
2 & 1.0 & $1264795 \pm 4420.12$ & $1.24 \pm 0.01$ \\
3 & 1.2 & $1236192 \pm 3462.24$ & $1.24 \pm 0.01$ \\
\hline
\end{tabular}

$\mathrm{n}$ is number of determinations, SD is the standard deviation 
Table 10: Robustness of piperine $(n=6)$

\begin{tabular}{llll}
\hline S. No. & Flow rate (ml/min) & Peak area (mean \pm SD) & Tailing factor (mean \pm SD) \\
\hline 1 & 0.8 & $1074930 \pm 1902.8$ & $1.11 \pm 0.008$ \\
2 & 1.0 & $1057483 \pm 1039.96$ & $1.12 \pm 0.005$ \\
3 & 1.2 & $1026428 \pm 2006.41$ & $1.11 \pm 0.04$ \\
\hline
\end{tabular}

$\mathrm{n}$ is number of determinations, SD is standard deviation

Table 11: Ruggedness of curcumin $(n=6)$

\begin{tabular}{llll}
\hline \multirow{2}{*}{ S. No. } & System 1 & System 2 \\
\cline { 2 - 4 } & Peak area (mean \pm SD) & \% Assay (mean \pm SD) & Peak area (mean \pm SD) \\
\hline 1 & $1265855 \pm 0.22$ & $100.8 \pm 0.22$ & $1261805 \pm 3793.2$ \\
\hline
\end{tabular}

$\mathrm{n}$ is number of determinations, SD is standard deviation

Table 12: Ruggedness of piperine $(n=6)$

\begin{tabular}{llll}
\hline S. No. & System 1 & System 2 \\
\cline { 2 - 4 } & Peak area (mean \pm SD) & \% Assay (mean \pm SD) & Peak area (mean \pm SD) \\
\hline 1 & $1054355 \pm 0.34$ & $99.9 \pm 0.34$ & $1056971 \pm 2626.7$ \\
\hline
\end{tabular}

$\mathrm{n}$ is number of determinations, SD is standard deviation

\section{Ruggedness}

Ruggedness of the method was estimated by comparing the results obtained from two different HPLC systems, which proves that the present assay method was rugged. The results were summarized in table 11 and 12 .

\section{LOD and LOQ}

LOD and LOQ were calculated from the standard deviation of response and slope of the calibration curve of curcumin and piperine. The LOD and LOQ were found to be $0.05 \mu \mathrm{g} / \mathrm{ml}$ and 0.17 $\mu \mathrm{g} / \mathrm{ml}$ for curcumin and $0.17 \mu \mathrm{g} / \mathrm{ml}$ and $0.53 \mu \mathrm{g} / \mathrm{ml}$ for piperine, which shown that the developed method was sensitive and it can detect and quantify at the lower concentration.

\section{DISCUSSION}

The present RP-HPLC method is a simple, precise, specific, accurate, linear and robust method for analyzing each component in the sample mixture. The previous study had reported that U. V. Spectroscopy methods [7-13] and HPLC methods [14-20] for curcumin and piperine individually and in combination with other drugs. In the present RP-HPLC method, we used PDA detector which prove selectivity of the method. The method was developed by using different buffer ratios at different flow rates. Finally methanol: water $(45: 55 \mathrm{v} / \mathrm{v})$ as mobile phase and Inertsil-ODS column as stationary phase was selected and separation was done for curcumin at 2.34 min and piperine at $3.09 \mathrm{~min}$. The method was validated as per ICH guidelines. Literature survey revealed, stability indicating RP-HPLC method for simultaneous estimation of curcumin and piperine with U. V. detector at different mobile phase and different column [16]. The separation was detected at $8.14 \mathrm{~min}$ for curcumin and $9.04 \mathrm{~min}$ for piperine. In the reported method, separation of curcumin and piperine was $5.71 \mathrm{~min}$ and $5.95 \mathrm{~min}$ respectively, longer than the present method. In the present method, PDA detector able to identify curcumin and piperine, and enhances the selectivity of the method. The method was validated according to ICH guidelines and results were in compliance of ICH guidelines. The linearity of the method had a good correlation with concentration and peak area. The correlation coefficient of curcumin and piperine was found to be 0.999 , which indicates good linear relationship over concentration range $20-80 \mu \mathrm{g} / \mathrm{ml}$. The $\%$ RSD values in intra-day and inter-day precision study were found to be less than 2 for curcumin and piperine, which indicate method was precise. The amount of drug recovery was $99.9 \%$ for curcumin and $99.6 \%$ for piperine. Hence, the present developed method was said to be suitable for the analysis of drugs in their pharmaceutical dosage form. Compared to the previous method, this method is selective, simple, sensitive, and separation was done at shorter run time.

\section{CONCLUSION}

The RP-HPLC method for estimation of curcumin and piperine was found to be simple, sensitive, precise and accurate. The present study of method development and method validation was as per ICH guidelines, and it meets the specific acceptance criteria. It is concluded that the method was precise, specific, linear, accurate, and robust within the limit. The present method development and method validation of curcumin and piperine can be used for intended purpose.

\section{ACKNOWLEDGMENT}

We would like to express our gratitude to the management $f$ Institute of Pharmaceutical Technology, Sri Padmavati Mahila Visvavidyalayam, Tirupati, Andhra Pardesh, India, for providing the research facilities. We would be also thankful to spectrum pharmaceuticals Pvt, Ltd, kukatpally, Hyderabad, India, for providing drug samples.

\section{AUTHORS CONTRIBUTIONS}

All authors had contributed equally

\section{CONFLICTS OF INTERESTS}

Declaration none

\section{REFERENCES}

1. Akram M, Uddin S, Ahmed A, Usman Ghani K, Hanan A Mohiuddin E, et al. Curcuma longa and curamin: a review article. ROM J Biol-Plant Biol 2010;55:65-70.

2. Steffi PF, Srinivasan M. Curcumin, a potent anti-carcinogenic polyphenol-a review. Asian J Pharm Clin Res 2014;7:1-8.

3. Noorafshan A, Esfahani SA. A review of the therapeutic effects of curcumin. Curr Pharm Design 2013;19:2032-46.

4. Daman Houri ZA, Ahmed A. A review on the therapeutic potential of Piper nigrum L. (Black pepper): the king of spices. Med Aromat Plants 2014;3:1-6.

5. Taqui SI, Shah AJ, Gilani AH. Blood pressure lowering and vasomodulator effects of piperine. J Cardiovasc Pharmacol 2008;52:452-8.

6. Amritpal S, Sanjiv D. Piperine-review of advances in pharmacology. Int J Pharm Sci Nanotechnol 2009;2:615-20.

7. Kiran S, Agarwal SS, Monica G. Development and validation of UV spectrophotometric method for estimation of curcumin in 
bulk drug and pharmaceutical dosage forms. Indian J Drug Dev Res 2012;4:375-80.

8. Ashwinder S, Vasudev RA. Development and validation of UV Spectrophotometric method for the estimation of curcumin in standard poly herbal formulations. J Young Pharm 2017; 9:4995.

9. Sukhjinder K, Taranjit K, Gurdeep K, Shivani V. Development and validation of UV-spectrophotometric method for estimation of hydroquinone in bulk marketed cream and prepared NLC formulation. Int J Appl Pharm 2017;9:102-8.

10. Narendra KS, Pramod K, Devendra KG, Satyendra S, Varun KS. UV Spectroscopic method development for estimation of piperine in chitrakadivati. Pharm Lett 2011;3:178-82.

11. Gupta V, Jain UK. Quantitave analysis of piperinein ayurvedic formulation by UV spephotometry. Int J Pharm Sci Res 2011;2:58-61.

12. Ginpreet A, Uria D, Vadodaria K. Simultaneous estimation of piperine, quercetin and curcumin in a mixture using UV-Visible spectrophotometer and method validation. Int J Ther Appl 2012;8:14-7.

13. Smita GL, Varsha MJ, Vilasrao JK. Development and validation of UV Spectrometric method for simultaneous estimation of galluc acid and piperine in herbal formulations. World J Pharm Sci 2014;3:948-56.

14. Suchitra P, Rajashree M. A new stability indicating RP-HPLC method for determination of curcumin: an application to a nanoparticulate formulation. Int J Pharm Pharm Sci 2016;8:149-55.

15. Santosh MK, Shaila D, Rajyalakshmi I, Sanjeev Rao I. RP-HPLC method for determination of piperine from Piper longum Linn. and Piper nigrum Linn. E-J Chem 2005;2:131-5.

16. Mata YC, Rajashree M. Development and validation of stability indicating RP-HPLC method for simultaneous estimation of curcumin and piperine in bulk mixture. World J Pharm Sci 2016;5:1262-76.
17. Sultana S, Vandana J. Development and validation of RP-HPLC method for simultaneous estimation of curcumin, piperine and camphor in an ayurvedic formulation. Int J Pharm Sci 2018;10:115-21.

18. Ganga G, Vikas S, Vitthal C, Kailas B. Development and validation of RP-HPLC method for the simultaneous determination of cinnamaldehyde and curcumin in the pharmaceutical formulation of lozenge. Int J Pharm Chem Sci 2015;4:311-6.

19. Kacchadiya KH, Shah JS, Maheshwari D. Analytical method development and validation for simultaneous estimation of embelin and curcumin in bulk and polyherbal formulation. Int J Pharm Res Bio-Sci 2014;3:548-58.

20. Moorthi C, Kathiresen K. Reverse phase high performance liquid chromatographic method for simultaneous estimation of curcumin and quercetin in pharmaceutical nanoformulation. Int J Pharm Pharm Sci 2013;5:475-8.

21. Niraj YV, Sejal P. Simultaneous estimation of curcuminoids, piperine and gallic acid in an ayurvedic formulation by validated high-performance thin layer chromatographic method. Asian J Pharm Clin Res 2016;9:117-22.

22. Shanmugam R, Gowthamarajan K, Priyanka DL, Madhuri K, Lokesh M, Elango K. Development and validation of simultaneous estimation method for curcumin and piperine by RP-UFLC. J Pharm Sci 2014;27:901-6.

23. Xiu MW, Zhang QZ, Jian Y, Rong HZ, Jun Z, Cai LJ, et al. Validated HPLC-MS/MS method for simultaneous determination of curcumin and piperine in human plasma. Trop J Pharm Res 2012;11:621-9.

24. Begam KMF, Ravichandran P, Kalai VM. Phytochemical analysis of some selected varieties of piper betle L. Int J Curr Pharm Res 2018;10:89-93.

25. Guidelines for validation of Analytical Procedures, Q2 (R1), ICH; 2005. 